\section{Nowhere to hide}

\author{
Dorothy Nelkin
}

Who Owns Information? From Privacy to Public Access. By Anne Wells Branscomb. BasicBooks: 1994. Pp. 241. \$25.

DESPITE its profound social impact, the information revolution has by and large been exempt from the public disputes that so frequently surround technological change in the United States. The technologies that make it possible to manipulate, store and gain access to information have intruded on privacy, threatened civil liberties and imposed on many rights; yet they have evoked surprisingly few expressions of public concern. In Who Owns Information?, a useful, accessible and often entertaining book, Anne Branscomb, an attorney and legal scholar, has laid out the social and legal dilemmas posed by communication and information technologies, suggesting the inadequacy of present laws and regulations to deal with their complex implications. She is especially concerned with the conflict between individual privacy and public access to information the blurring of the lines between public and private domains of information.

Branscomb poses nine questions. Who owns your name and address? Your telephone number? Your medical history? Your image? Your electronic messages? Video entertainment? Religious information? Computer software? And government information? In each case, she provides examples to illustrate how information systems such as direct mail and telemarketing work. She describes the commercial and political value of personal information, providing titbits of amazing and discouraging information for those in the United States. When we file a post-office change-of-address card, it becomes available to direct-mail marketeers. When we dial an 800 number to ask for information, we are likely to be placed on a telemarketing list. When we subscribe to a magazine, use a credit card, send an e-mail message or visit a doctor, records become available that may be accessed by organizations with commercial interests.

Branscomb shows how technological advances put a new spin on familiar dilemmas. In the academic disputes over the ownership of the Dead Sea Scrolls, biblical scholars working with computers and photographic images are carrying on the traditional struggles among priests over custody of religious dogma. Debates about computer software add new di- mensions to intellectual property claims. The legal status of our information assets, she argues, is alarmingly vague.

Three areas of law bear on the ownership of information in the United States: First Amendment rights to protect freedom of the press, intellectual property rights to encourage innovation and privacy rights to protect individuals. These were established well before recent technological changes. Branscomb therefore argues for "a coherent effort to rationalize the legal infostructure ( $\mathrm{sic}$ ) of the information age" on the basis of a clear set of ethical values and guiding principles that Americans would be prepared to follow.

But what values and principles would, in fact, be acceptable to most Americans? Despite the instrusiveness of information technologies, criticisms have mainly come from an élite - ethicists, sociologists, lawyers and other professionals. There is a striking absence of organized public concern. Indeed, Americans seem to care little about privacy. Although computerized databanks allow bureaucratic authorities to have easy access to personal information about credit ratings, school performance, housing, medical history, tax status and even genetic profile, few people seem outraged. More and more information is available to employers, insurers, advertizers, banks, school systems and other institutions that exercise control over our lives, yet we accept new information technologies as useful and benign. There is little public outcry against the surveillance gimmicks that photograph us in department stores, or

the 'muzak' that intrudes on our privacy in supermarkets and airports. There is no apparent public concern about the privacy implications of the Clinton administration's proposal for a universal health card, even though it would contain, in accessible form, the complete health history of every American.

Popular magazines and television and radio talk shows are full of lurid and embarrassing personal confessions, and the audiences seem to relish intrusions on privacy. To an amazing degree, people talk about their own personal problems in public. Indeed, relinquishing privacy is seen as a way to solve personal problems; far from demanding privacy, Americans let it 'all hang out'. Perhaps this explains why, despite their obvious intrusions, information technologies have not been resisted.

The rapid development of computerized databanks, allowing a striking level of institutional control over individuals, has evoked some professional concern. Yet it has not brought about a great deal of public resistance. People see information technologies through their computers and fax machines, which have been marketed as a way of empowering and liberating the individual - of expanding individual choice. Perhaps no industry has been more successful than the information-technology industry at turning the latest gimmick - the extra megabyte, the latest fax machine, and now the videophone - into a dire necessity. The gadgets seem to give people more, not less, control,

blinding them to potential abuses.

Nor do we seem to care that along with the information highway comes the risk of hegemonic control over the messages we receive from the media. We welcome the advances in information technology that have brought innumerable television channels as 'pluralism', ignoring their role in the corporate manipulation of consumer taste and cash flow. And we welcome proposals for electronic democracy, failing to see the difference between the inundation of information and reflective political exchange.

Branscomb nicely sorts out the critical legal and ethical dilemmas generated by new information technologies and makes an effective case for better laws. But she underestimates the political will to control technologies that are widely viewed more as symbols of progress and icons of US ingenuity than as commercial and political products that threaten individual rights. $\square$

Dorothy Nelkin is in the Department of Sociology, New York University, 269 Mercer Street, New York, New York 10003, USA. 